\begin{tabular}{|l|l|}
\hline JURNAL ABDI MASYA & Volume 1 No 2 \\
& Mei 2021 \\
E-ISSN : 2774-2849 & Pp 72-76 \\
Website : https://jurnal.sttw.ac.id/index.php/abma/about \\
\hline P-ISSN : 2774-2881
\end{tabular}

\title{
RANCANG BANGUN MESIN PENCACAH RUMPUT UNTUK PENINGKATAN EFEKTIVITAS KONSUMSI PAKAN TERNAK DI SUKOHARJO
}

\section{DESIGN OF BUILDING MACHINE TO INCREASE OF CONSUMPTION EFFECTIVENESS ANIMAL FEED IN SUKOHARJO}

\author{
Margono $^{1 *}$, Nugroho Tri Atmoko², Bambang Hari Priyambodo ${ }^{3}$, Suhartoyo ${ }^{4}$, Sang Alang \\ Awan $^{5}$
}

1, 2, 3, 4, 5 Program Studi Teknik Mesin, Sekolah Tinggi Teknologi Warga, Surakarta, Indonesia *E-mail: arghaa849@gmail.com / margono@sttw.ac.id

\begin{abstract}
ABSTRAK
Kebutuhan akan rumput gajah untuk pakan ternak di desa Curidan, Sukoharjo terus meningkat, hal tersebut berbanding lurus dengan populasi sapi yang juga meningkat. Rumput harus disediakan peternak sebagai pakan utama ternak setiap harinya, akan tetapi tingkat efektivitas konsumsi pakan ternak masih kurang. Kebanyakan peternak masih menggunakan proses pencacah rumput secara konvensional. Sehingga apabila rumput dalam jumlah yang cukup banyak maka dibutuhkan waktu dan tenaga yang lebih banyak. Tujuan dilaksanakannya pengabdian masyarakat dengan menciptakan mesin tepat guna untuk membantu peran manusia dalam proses pencacah rumput dengan menggunakan mesin Pencacah. Mesin ini diharapkan mampu meningkatkan efektivitas dan efisiensi produksi pakan ternak. Hasil program menunjukkan bahwa rata-rata kapasitas produksi mengalami peningkatan sebesar $250 \%$ dari $200 \mathrm{~kg} / \mathrm{jam}$ menjadi $500 \mathrm{~kg} / \mathrm{jam}$. Penggunaan mesin baru tetap bisa menjaga kualitas pada rumput sebagai sumber protein. Singkatnya, program pengabdian masyarakat telah memberikan perubahan positif dalam hal peningkatan efektivitas proses pencacahan pakan ternak bagi peternak sapi di desa Curidan, Parangjoro, Grogol, Sukoharjo.
\end{abstract}

Kata Kunci : rumput gajah, mesin pencacah, efektivitas

\section{ABSTRACT}

The need for elephant grass for animal feed in the village of Curidan, Sukoharjo continues to increase, this is directly proportional to the increasing population of cows. Grass must be provided by breeders as the main feed for livestock every day, but the level of effectiveness of animal feed consumption is still lacking. Most breeders still use the conventional grass chopper process. So that if there is a sufficient amount of grass, it will take more time and energy. The aim of implementing community service is to create an appropriate machine to assist the human role in the grass chopper process using a chopper machine. This machine is expected to increase the effectiveness and efficiency of animal feed production. The program results show that the average production capacity has increased by $250 \%$ from $200 \mathrm{~kg} / \mathrm{hour}$ to $500 \mathrm{~kg} / \mathrm{hour}$. The use of new machines can still maintain the quality of the grass as a source of protein. In short, the community service program has made positive changes in terms of increasing the effectiveness of the animal feed chopping process for cattle farmers in the village of Curidan, Parangjoro, Grogol, Sukoharjo.

Keywords: elephant grass, chopper, effectiveness

Submit : 25 Maret 2021 Revision : 7 Mei 2021 Accepted: 10 Mei 2021 Published : 28 Mei 2021 


\section{PENDAHULUAN}

Sebagian besar penduduk di desa curidan, parangjoro, grogol, sukoharjo berprofesi sebagai peternak, salah satu ternak yang dipelihara adalah sapi. Populasi ternak sapi di desa curidan sebesar 247 sapi muda dan 400 ekor sapi dewasa [1]. Sapi merupakan salah satu ternak yang mempunyai kontribusi terbesar sebagai penghasil daging dan susu murni. Dalam pemeliharaannya, peternak harus menyediakan pakan dalam jumlah yang cukup banyak. Biaya operasional yang dikeluarkan untuk pakan menghabiskan sekitar 60-70\%, sehingga perlu pengelolaan yang efektif dan efisien [2]. Jenis pakan ternak yang paling penting adalah rumput yang merupakan $70 \%$ dari makanan ternak ruminansi [3].

Hijauan makanan ternak (forages) merupakan bahan makanan atau pakan utama bagi kehidupan ternak serta dasar dalam usaha pengembangan peternakan [4], rumput harus disediakan peternak sebagai pakan utama ternak setiap harinya. Sedangkan kebanyakan peternak masih menggunakan pencacahan secara manual dengan sabit, parang ataupun alat konvensional lainnya, sehingga membutuhkan waktu dan tenaga kerja yang banyak [5]. Pencacahan dilakukan untuk memperkecil ukuran bahan sehingga memudahkan dalam pembuatan pakan ternak [3]. Oleh sebab itu, pencacahan secara manual tidak efektif untuk diterapkan [6]. Sehingga sebuah mesin pencacah dibutuhkan [7], sebagai sarana untuk membantu para peternak dalam merajang rumput untuk mempermudah penyediaan pakan dan menghemat tenaga pekerja [8].

Mesin pencacah harus memenuhi kebutuhan dan kondisi peternak sapi yang ada di desa curidan, supaya dalam proses mencacah atau merajang rumput dapat menghemat waktu dan tenaga yang dikeluarkan. Dalam proses pembuatan mesin pencacah rumput ini membutuhkan rangka yang kuat, pisau tajam agar sampai beberapa kali pemotongan, ergonomis dan harganya terjangkau. Hal yang paling utama adalah mesin atau alat pencacah pakan ternak tersebut berfungsi secara maksimal sesuai fungsi dan kebutuhannya.

\section{METODE}

Dari hasil survey di lokasi mitra diperoleh beberapa permasalahan, salah satunya adalah peningkatan efektivitas konsumsi pakan ternak UKM "Tekat Manunggal" di desa Curidan rt 02/rw 7, Parangjoro, Grogol, Sukoharjo. Solusi yang ditawarkan untuk mengatasi permasalahan pada pencacah atau perajang rumput pertama kali adalah melakukan koordinasi dan identifikasi prioritas permasalahan mitra.

Dalam mengatasi masalah ini adalah mengganti proses pencacah rumput konvesional dengan proses mekanis yang menggunakan mesin pencacah yang menghasilkan kecepatan optimum sehingga dapat menghasilkan ukuran kecil, di samping itu juga dengan tetap mempertahankan mutunya sebagai sumber energi, dan protein. Proses rancang bangun diawali dengan tahap perancangan desain menggunakan software komersial Solidwork dimana komponen yang di desain menggunakan software tersebut meliputi rangka besi siku dengan ukuran $25 \times 25 \mathrm{~mm}$ tebal $3 \mathrm{~mm}$, transmisi menggunakan pully diameter $10 \mathrm{~cm}$ dan $20 \mathrm{~cm}$ dihubungkan dengan V-belt ukuran A-6, pisau pencacah menggunakan material high speed steel dengan sambungan baut untuk, serta cover plat dengan tebal 1,2 mm, kemudian dilanjut dengan pembuatan mesin pencacah menggunakan peralatan bengkel yang ada di laboratorium pengelasan di Sekolah Tinggi Teknologi "Warga" Surakarta meliputi perakitan rangka dengan proses pengelasan.

\section{HASIL DAN PEMBAHASAN}

Kegiatan pengabdian dilakukan sesuai rencana yang sudah disusun oleh tim penyelenggaraan, mulai dari perisapan yaitu berupa kunjungan dengan tujuan pendekatan kepada UKM "Tekat Manunggal" serta observasi kepada pihak terkait, setelah tim 
mendapatkan data mengenai keluhan serta masalah yang dihadapi, tim kemudian menyusun rancangan sebagai solusi dari masalah yang dihadapi. Dari informasi yang di dapat, pakan ternak merupakan produksi terbesar dalam usaha peternakan.

Dari pertimbangan diatas tim memutuskan untuk merancang mesin pencacah rumput dengan saluran masuk dari samping dan saluran keluar berada di bawah dengan hasil rancangan seperti disajikan pada Gambar 1. Komponen mesin diantaranya yaitu penggerak dengan menggunakan motor bensin dengan daya $5.5 \mathrm{hp}$, rangka besi siku dengan ukuran $25 \times 25 \mathrm{~mm}$ tebal $3 \mathrm{~mm}$, transmisi menggunakan pully diameter $10 \mathrm{~cm}$ dan $20 \mathrm{~cm}$ dihubungkan dengan $V$-belt ukuran A-6, pisau pencacah menggunakan material high speed steel dengan sambungan baut untuk, serta cover plat dengan tebal 1,2 mm. Indikator keberhasilan kegiatan ini adalah terwujudnya mesin pencacah rumput untuk pakan ternak sapi.

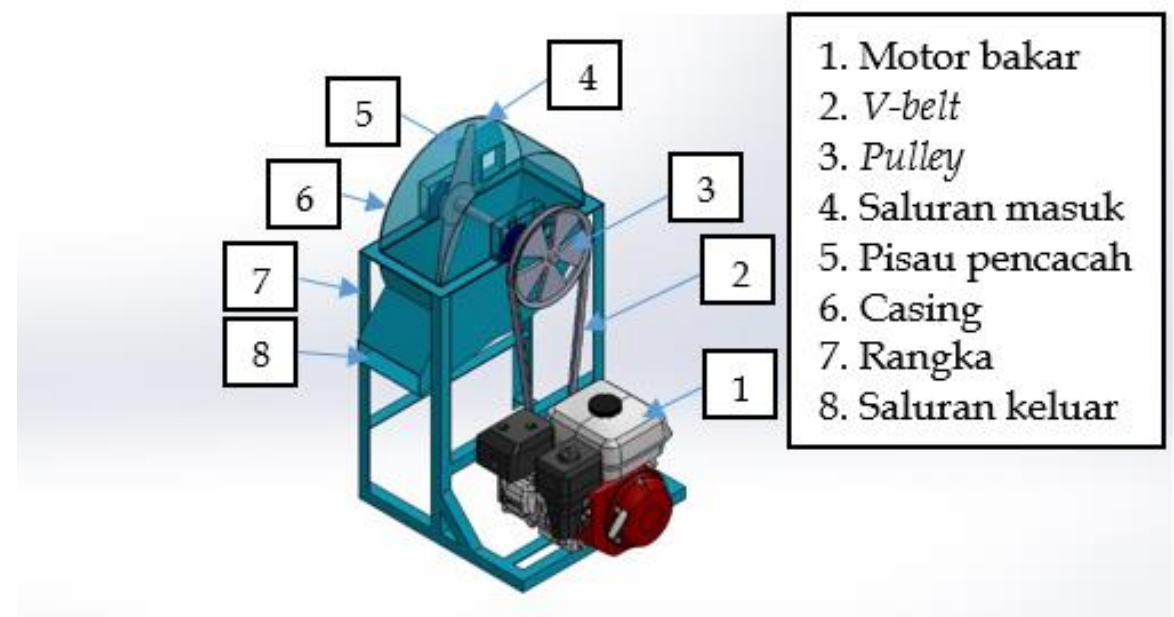

Gambar 1. Skema Mesin Pencacah Rumput

Hasil rancang bangun mesin pencacah rumput dapat dilihat pada Gambar 2. Mesin pencacah rumput ini menggunakan motor bakar sebagai tenaga penggerak dan dikombinasi dengan pulley, skema tersebut menghasilkan kecepatan putar dikisaran $1500 \mathrm{rpm}$. Prinsip kerja dari mesin yang dirancang untuk mencacah rumput adalah meneruskan gerakan putaran dari motor penggerak dengan menggunakan pulley sebagai penggerak yang diteruskan ke poros melalui poros penggerak.

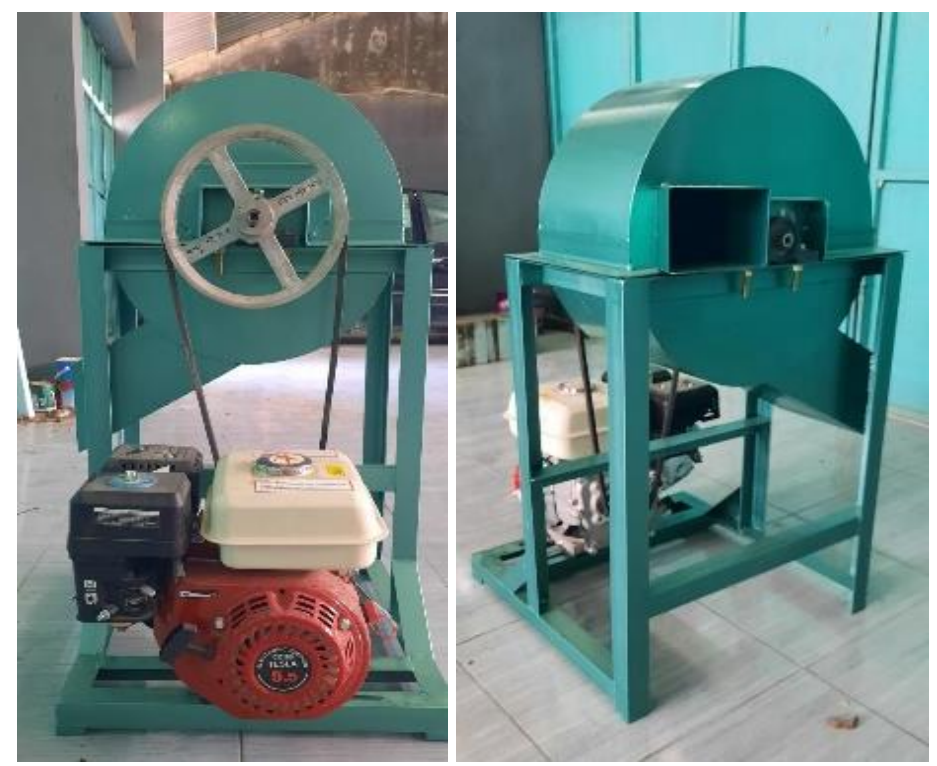


Gambar 2. Mesin Pencacah Rumput

Berdasarkan hasil kegiatan yang telah dilakukan, maka dapat dibuktikan bahwa terdapat perbedaan signifikan antara proses pencacah pakan ternak secara manual dibandingkan dengan menggunakan mesin pencacah. Dimana proses pencacahan pakan ternak konvensional tidak efektif dan efisien karena proses produksi pakan ternak dalam satu hari hanya mampu menghasilkan produksi sebanyak $200 \mathrm{~kg} / \mathrm{jam}$ pakan ternak dengan menggunakan tenaga kerja 2 orang serta hasil pencacahannya tidak seragam (ada yang panjang $>10 \mathrm{Cm}$, ada yang pendek $<10 \mathrm{Cm}$ ), sedangkan setelah menggunakan mesin pencacah rumput menghasilkan pakan ternak dalam bentuk kecil-kecil dengan panjang berkisar antara 5-10 Cm serta dapat memudahkan ternak untuk mencerna makanan tersebut, seperti yang disajikan dalam Gambar 3.
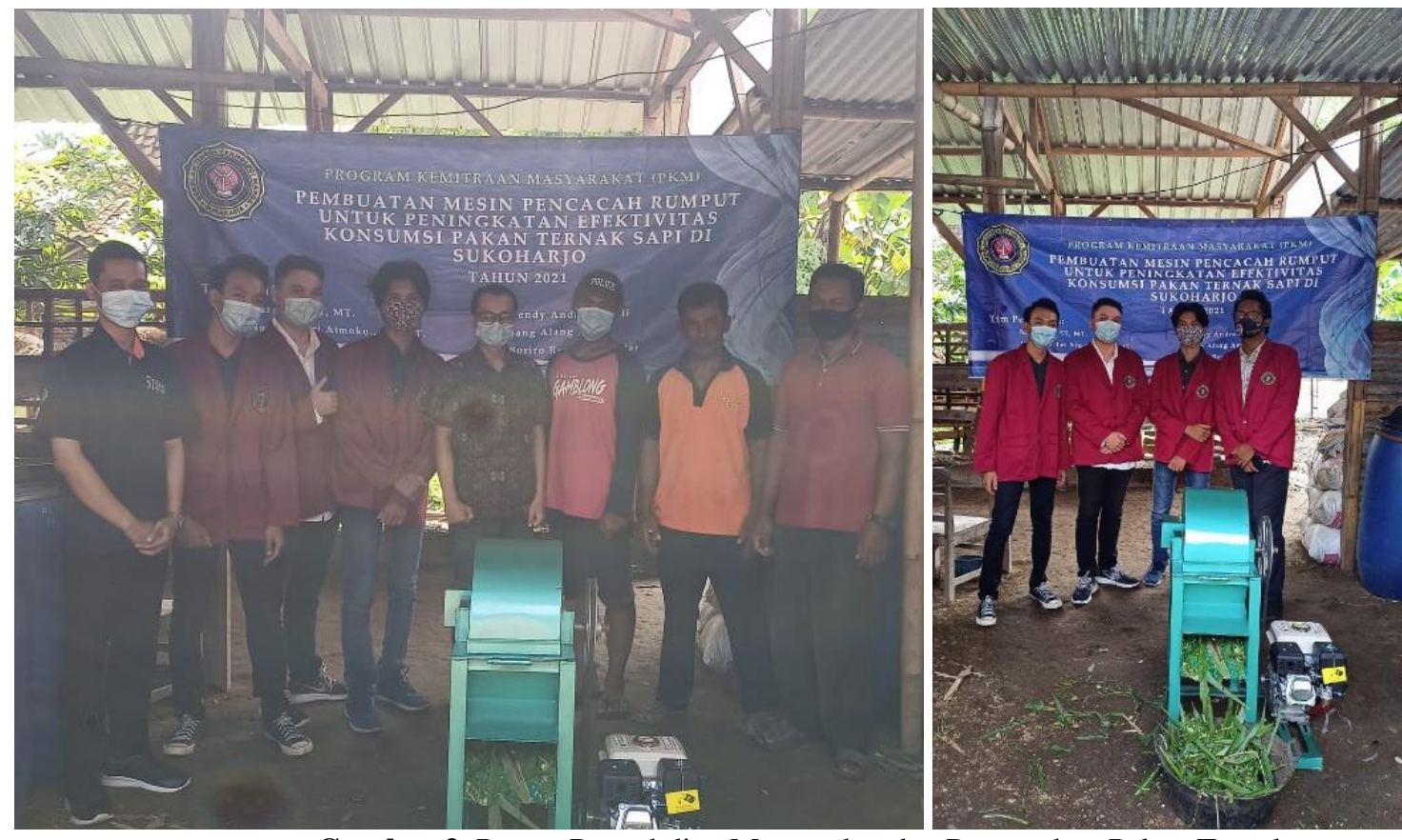

Gambar 3. Proses Pengabdian Masyarakat dan Pencacahan Pakan Ternak

Analisis produktivitas hasil rancang bangun mesin pencacah rumput adalah dengan melakukan simulasi pada mesin. Pengolahan dengan metode konvensional untuk produksi pakan ternak dalam satu hari hanya mampu menghasilkan produksi sebanyak $200 \mathrm{~kg} / \mathrm{jam}$ pakan ternak dengan menggunakan tenaga kerja 2 orang, sedangkan dengan menggunakan mesin pencacah rumput kapasitas produksi meningkat menjadi $500 \mathrm{~kg} / \mathrm{jam}$. Sehingga kapasitas produksi sebelum dan sesudah menggunakan mesin dapat dihitung dengan persamaan (1) berikut:

$\eta K P=\frac{K P_{A}}{K P_{M}} \times 100 \%$

$\eta K P=\frac{500}{200} \times 100 \%$

$\eta K P=250 \%$

Dimana:

$\eta \mathrm{KP}=$ Efisiensi Kapasitas produksi $(\%)$

DOI: $\underline{\text { https://doi.org/10.52561/abma.v1i2.132 }}$ 
$\mathrm{KP}_{\mathrm{M}} \quad=$ Kapasitas produksi manual $(\mathrm{Kg} / \mathrm{jam})$

$\mathrm{KP}_{\mathrm{A}} \quad=$ Kapasitas produksi menggunakan alat $(\mathrm{Kg} / \mathrm{jam})$

Dengan demikian, penggunaan mesin pencacah dapat meningkatkan kapasitas produksi dari $200 \mathrm{~kg} / \mathrm{jam}$ menjadi $500 \mathrm{~kg} / \mathrm{jam}$ dalam waktu satu jam, atau meningkat 250 persen. Sebagai catatan bahwa peningkatan ini dicapai dengan tetap memperhatikan kualitas mutu rumput gajah seperti pada penggunaan tenaga manusia yang tetap mempertahankan karakter rumput. Manfaat penggunaan mesin pencacah selain meningkatkan kapasitas produksi juga dapat mengurangi biaya operasional serta waktunya lebih efektif dan efisien, sehingga dapat meningkatkan kesejahteraan bagi UKM "Tekat Manunggal”.

\section{KESIMPULAN}

Dengan mengaplikasikan mesin pencacah rumput di UKM "Tekat Manunggal" sebagai upaya mengurangi pengolahan pakan ternak secara konvensional dapat dikatakan berjalan dengan lancar dan sukses, dikarenakan mampu meningkatkan kapasitas produksi sebesar 250 persen. Singkatnya, program pengabdian masyarakat telah memberikan perubahan positif dalam hal peningkatan efektivitas proses pencacahan pakan ternak bagi peternak sapi di desa Curidan, Parangjoro, Grogol, Sukoharjo.

\section{UCAPAN TERIMA KASIH}

Ucapan terima kasih disampaikan pada LPPM Sekolah Tinggi Teknologi "Warga" Surakarta yang telah memberi kesempatan pada penulis untuk melakukan program pengabdian masyarakat. Demikian pula dengan para peternak di desa Curidan rt 02/rw 7, Parangjoro, Grogol, Sukoharjo yang turut berpartisipasi aktif dalam penyuluhan Program Pengabdian Kepada Masyarakat ini.

\section{DAFTAR PUSTAKA}

[1] BPS, "Kabupaten Sukoharjo," 2021.

[2] H. Handajani, "Optimalisasi Substitusi Tepung Azolla Terfermentasi Pada Pakan Ikan Untuk Meningkatkan Produktivitas Ikan Nila Gift," J. Tek. Ind., vol. 12, no. 2, pp. 177$181,2006$.

[3] N. I. F. Nisa, A. Aminudin, and Y. A. Fahrudi, "Aplikasi Mesin Pencacah Pakan Ternak Serbaguna Sebagai Upaya Mengurangi Pengolahan Pakan Ternak Secara Konvensional," JAST J. Apl. Sains dan Teknol., vol. 3, no. 1, pp. 43-49, 2019.

[4] W. K. Sugandi, A. Yusuf, and M. Saukat, "Rancang Bangun Dan Uji Kinerja Mesin Pencacah Rumput Gajah Untuk Pakan Ternak Dengan Menggunakan Pisau Tipe Reel," J. Ilm. Rekayasa Pertan. dan Biosist., vol. 4, no. 1, pp. 200-206, 2016.

[5] N. Sari and M. Achmad, "Uji Kinerja Dan Analisis Biaya Mesin Pencacah Pakan Ternak ( Chopper )," Agritechno, vol. 11, no. 2, pp. 113-120, 2018.

[6] N. A. Mutaqin, Margono, B. H. Priyambodo, and M. V. Hermawan, "Mesin Pencacah Singkong Sebagai Pakan Ternak Sapi Untuk Peningkatan Kesejahteraan UKM Sido Mulyo di Kabupaten Karanganyar," in Prosiding Seminar Nasional Unimus, 2020, pp. 948-953.

[7] Sukadi and Novarini, "Rancang Bangun Mesin Perajang Singkong Multi Pisau," $J$. Inov., vol. 1, no. 2, pp. 1-4, 2018.

[8] P. Rachmawati, "Rancang Bangun Mesin Perajang Singkong yang Memenuhi Aspek Ergonomis untuk Meningkatkan Produktivitas Pekerja," J. Engine Energi, Manufaktur, dan Mater., vol. 3, no. 2, pp. 66-72, 2019. 